\title{
THE IMPACT OF COVID-19 ON PROTECTED AREAS: A SYSTEMATIC REVIEW
}

\author{
Carla Molteni \\ Hungarian University of Agriculture and Life Sciences \\ ORCID: 0000-0001-7476-6568
}

\begin{abstract}
Understanding the effects of COVID-19 on protected areas (PAs) is very important because these spaces are crucial for international policies for biodiversity conservation and sustainable development. Therefore, the aim of this paper was to fully understand the impacts of COVID-19 on terrestrial and marine protected areas (PAs). To address this concern, we conducted a systematic review on the literature of the impacts of the pandemic on PAs. We used the Preferred Reporting Items for Systematic Reviews and Meta-Analyses (PRISMA) guidelines which helps authors to follow certain specific criteria when they make a systematic review on a topic. Following it, we examined five databases, together with complementary search perform in Google Scholar. Lastly, we made a qualitative assessment of articles retrieved, studying short-term changes, and identifying positive and negative effects, as well as challenges and opportunities that arise. After identifying, screening, and selecting, we included 14 journal articles published between February 2020 and May 2021. In the results we showed how the new virus-related restrictions affected the ecological, social and management dimensions of PAs. We discuss how these conserved areas gained social relevance during the pandemic but, at the same time, the vulnerability of related actors increased. Also, we suggested that some social problems differed between develop and developing countries. Additionally, digital tendencies consolidated in PAs management, research, and engagement. Overall sustainability of these places was compromised. We concluded that COVID-19 made humans to see everything through the lenses of health and PAs were not the exception.
\end{abstract}

Keywords: COVID-19, Protected Areas, National Park, Systematic Review, Ecological Effects, Impact on Parks Management, Social Impacts of Conservation Initiatives. 


\section{Una revisión sistemática sobre el impacto del covid-19 en áreas protegidas}

Resumen: Esta investigación contribuye a la comprensión de los impactos de la pandemia del COVID-19 en áreas protegidas (PAs), terrestres y marinas. Por un lado, analizamos sus efectos sobre las dimensiones ecológicas, sociales y administrativas de las PAs. Comprender los impactos de la pandemia sobre las PAs es importante debido a que estos espacios son estratégicos para las políticas internacionales de conservación de la biodiversidad y el desarrollo sostenible. Para abordar esta problemática, realizamos una reseña sistemática de la literatura sobre los impactos de la pandemia en los espacios de conservación. Utilizamos las pautas de Preferred Reporting Items for Systematic Reviews and MetaAnalyses (PRISMA) que es una guía que establece criterios para realizar revisiones sistemáticas de la literatura de un tópico de interés. A partir de ella, revisamos cinco bases de datos y lleva a cabo a una búsqueda complementaria en Google Scholar. Tras identificar, examinar y seleccionar, incluimos 14 artículos, publicados entre febrero 2020 y mayo 2021. Por último, llevamos a cabo un análisis cualitativo de los artículos seleccionados, estudiando los cambios a corto plazo, los efectos positivos y negativos, así como los retos y oportunidades que emergieron. En las discusiones, explicamos que las áreas protegidas adquirieron relevancia social durante la pandemia al mismo tiempo que se incrementó la vulnerabilidad de ciertos actores y medios de financiación de los parques. Además, los espacios tuvieron problemáticas sociales distintivos en países desarrollados y en desarrollo. En suma, la sustentabilidad de las PAs se vio comprometida. Concluimos que la pandemia nos hizo ver todo a través de las lentes de la salud, y las áreas protegidas no fueron la excepción.

Palabras clave: COVID-19, Parques nacionales, Áreas protegidas, Revisión sistemática, Impacto ecológico, Administración de parques, Impacto social de políticas de conservación. 
THE IMPACT OF COVID-19 ON PROTECTED AREAS: A SYSTEMATIC REVIEW

\section{Carla Molteni}

MSc student in Regional and Environmental Economics in Hungarian University of Agriculture and Life Sciences (Magyar Agrár-és Élettudományi Egyetem) Kaposvari Campus, Hungary. BSc in History at the University Torcuato Di Tella, Argentina. Carla is currently conducting research on the social impact and public acceptability of protected areas in Spain. She has experience in environmental and conservation NGOs in Argentina.

Email: carla.molteni@uni-mate.hu,carlamolteni@hotmail.com 


\section{Introduction}

Protected areas (PAs) have long been considered as cornerstones of biodiversity conservation. They are critical tools to maintain ecosystem services, habitat integrity, prevent species extinction, maintain forest coverage, and reduce human pressure on natural capital (Ma et al. 2020; Secretariat of the Convention on Biological Diversity 2020; UNEP-WCMC and IUCN 2020). PAs also play an important role in sustainable development policies, like United Nations Sustainable Development Goals (2015) and the Biodiversity Strategy from European Union for 2030 (Jones, Graziano, and Dimitrakopoulos 2020). Furthermore, the pandemic put into evidence that biodiversity loss is not just a threat for ecosystem health, but also to the health of humans. This has generated new momentum to realize the benefits of protected and conserved areas to their full potential (UNEP-WCMC and IUCN 2020). Therefore, nowadays scientists and policymakers need to consider the impacts of COVID-19 on protected landscapes when analyzing PAs. The new virus disrupted humankind activities in several ways and PAs were not the exception. Thus, it is important to explore the diverse impacts of the pandemic on conserved areas and its positive and negative effects. It is also relevant to identify the medium and longterm changes as well as the challenges and opportunities that arise.

To address this concern, we conducted a systematic review of the recent literature about the effects of COVID-19 pandemic on PAs. We analyzed the ecological, social and management dimensions of protected landscapes and identifies the negative and positive effects. We also studied the responses, short-term impacts and explores long-term repercussions within an opportunities and challenges framework. 


\section{Material and methods}

In this paper we follow established procedures for systematic reviews based on Preferred Reporting Items for Systematic Reviews and Meta-Analyses (PRISMA) criteria (Beller et al. 2013) and on the guideline in conservation and environmental management (Pullin and Stewart 2006). We developed a review protocol following these guidelines. Firstly, we built a search strategy based on three main keywords: 'Impact', 'COVID-19' and 'Protected Area'. For the last keyword, we used the International Union for Conservation of Nature ranking system and UNESCO categories to select 'Protected Area', 'Nature Reserve', 'National Park', 'World Heritage (Natural) Site', 'Biosphere Reserve' and 'Conservation of Wildlife'. We conducted a literature search using five databases: ScienceDirect, Wiley Online Library, Taylor and Francis Online, SpringerLink, and Emerald. We also carried out a complementary search in Google Scholar to maximize comprehensiveness and mitigate publication bias (Gusenbauer, Haddaway, 2020). All the combinations of keywords resulted in five searches for each of the database selected. Additionally, we introduced eligibility criteria for including and excluding studies. Thus, we included original research articles in English from any country and studies published since the year 2020. We did not include reports, short communications, and editorial essays. Furthermore, we established a final selection criterion: we included an article if the abstract indicated a qualitative or quantitative assessment of the effects of the pandemic on PAs.

Initially, we identified 6887 research articles through database search (Figure 1). Then, we screened the titles of those articles and selected 182. Finally, after reading the abstracts of those studies, we included 14 research articles. Searches were conducted between March 2020 and May 2021.

Figure 1. Overview of research process, including number of papers identified at different stages.

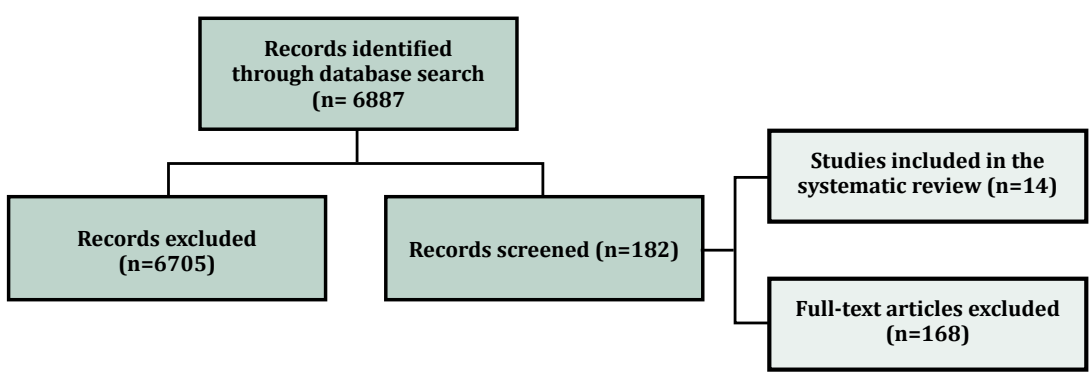

Source: Flow diagram distributed under the terms of the Creative Commons Attribution License, PRISMA. 


\section{Results}

Table 1. Key findings.

\begin{tabular}{|c|c|c|c|c|c|c|}
\hline Ref & Subject & $\begin{array}{l}\text { Analysis } \\
\text { methods }\end{array}$ & Location & Sample & Key findings & $\begin{array}{l}\text { Date of } \\
\text { research }\end{array}$ \\
\hline $\begin{array}{l}\text { (Smith et al. } \\
\text { 2021) }\end{array}$ & $\begin{array}{c}\text { Impact on } \\
\text { national } \\
\text { parks' } \\
\text { management. }\end{array}$ & $\begin{array}{l}\text { Qualitative } \\
\text { analysis. }\end{array}$ & $\begin{array}{l}\text { South } \\
\text { Africa }\end{array}$ & $\begin{array}{l}\mathrm{n}=467 \\
\text { park staff }\end{array}$ & $\begin{array}{l}\text { Interdependencies between } \\
\text { people-nature. Opportunities } \\
\text { for innovative approaches, } \\
\text { partnership, collaboration. }\end{array}$ & $03 / 2021$ \\
\hline $\begin{array}{l}\text { (Miller- } \\
\text { Rushing } \\
\text { et al. 2021) }\end{array}$ & $\begin{array}{l}\text { Impact on } \\
\text { management. }\end{array}$ & $\begin{array}{l}\text { Qualitative } \\
\text { analysis }\end{array}$ & U.S. & $\begin{array}{c}\text { Not } \\
\text { mentioned. }\end{array}$ & $\begin{array}{l}\text { Need to improve flexibility and } \\
\text { strengthening the management } \\
\text { systems. Management needs } \\
\text { clear priorities. }\end{array}$ & $05 / 2021$ \\
\hline $\begin{array}{l}\text { (Anand and } \\
\text { Kim 2021) }\end{array}$ & $\begin{array}{l}\text { Impact on } \\
\text { economic } \\
\text { activities } \\
\text { around PAs }\end{array}$ & $\begin{array}{l}\text { Quantitative } \\
\text { analysis }\end{array}$ & Africa & & $\begin{array}{l}\text { Level of economic activity was } \\
\text { entirely reduced around PAs } \\
\text { during the pandemic. }\end{array}$ & $04 / 2020$ \\
\hline $\begin{array}{l}\text { (McGinlay } \\
\text { et al. 2020) }\end{array}$ & $\begin{array}{l}\text { Impact on } \\
\text { management } \\
\text { and measures } \\
\text { taken. }\end{array}$ & $\begin{array}{l}\text { Mixed } \\
\text { methods }\end{array}$ & $\begin{array}{l}\text { UK, Spain, } \\
\text { Italy, } \\
\text { Estonia, } \\
\text { Germany, } \\
\text { Poland, } \\
\text { Slovenia, } \\
\text { Sweden. }\end{array}$ & $\begin{array}{l}\mathrm{n}=14 \\
\text { managers } \\
\text { from } 14 \\
\text { PAs }\end{array}$ & $\begin{array}{l}\text { Safety measures increased the } \\
\text { risk and extent of disturbance in } \\
\text { remote sensitive areas of PAs. }\end{array}$ & $11 / 2020$ \\
\hline $\begin{array}{l}\text { (Terry et al. } \\
\text { 2021) }\end{array}$ & $\begin{array}{l}\text { Impact } \\
\text { on noise } \\
\text { pollution. }\end{array}$ & $\begin{array}{l}\text { Quantitative } \\
\text { analysis. }\end{array}$ & $\begin{array}{l}\text { Boston, } \\
\text { U.S. }\end{array}$ & & $\begin{array}{l}\text { Unexpected effects of noise } \\
\text { pollution in PAs. Vehicular traffic } \\
\text { volume is not a linear predictor } \\
\text { of noise pollution in PAs. }\end{array}$ & $05 / 2020$ \\
\hline $\begin{array}{l}\text { (Cahyadi } \\
\text { and } \\
\text { Newsome } \\
\text { 2021) }\end{array}$ & $\begin{array}{l}\text { Impact on } \\
\text { tourism }\end{array}$ & $\begin{array}{l}\text { Qualitative } \\
\text { analysis. }\end{array}$ & Indonesia & $\begin{array}{c}\text { Not } \\
\text { mentioned. }\end{array}$ & $\begin{array}{l}\text { Over-tourism can lead to } \\
\text { negative perceptions }\end{array}$ & $04 / 2020$ \\
\hline $\begin{array}{l}\text { (Koju et al. } \\
\text { 2021) }\end{array}$ & $\begin{array}{l}\text { Impact } \\
\text { on illegal } \\
\text { activities }\end{array}$ & $\begin{array}{l}\text { Mixed } \\
\text { methods }\end{array}$ & Nepal & $\begin{array}{c}\text { Not } \\
\text { mentioned. }\end{array}$ & $\begin{array}{l}\text { Illegal activities increased } \\
\text { during lockdown because of less } \\
\text { security personnel. }\end{array}$ & $09 / 2020$ \\
\hline $\begin{array}{l}\text { (Patterson } \\
\text { Edward } \\
\text { et al. 2021) }\end{array}$ & $\begin{array}{l}\text { Impact on } \\
\text { marine } \\
\text { national park }\end{array}$ & $\begin{array}{l}\text { Quantitative } \\
\text { analysis. }\end{array}$ & $\begin{array}{l}\text { Gulf of } \\
\text { Mannar, } \\
\text { India }\end{array}$ & & $\begin{array}{l}\text { Scaling down of adverse man- } \\
\text { made factors in number and } \\
\text { intensity leads to improved } \\
\text { environmental health }\end{array}$ & $06 / 2020$ \\
\hline $\begin{array}{l}\text { (China et al. } \\
\text { 2021) }\end{array}$ & $\begin{array}{l}\text { Impact on } \\
\text { coral reef } \\
\text { diversity and } \\
\text { evenness }\end{array}$ & $\begin{array}{l}\text { Quantitative } \\
\text { analysis. }\end{array}$ & $\begin{array}{l}\text { Gulf of } \\
\text { Aqaba, } \\
\text { in Eilat, } \\
\text { Israel }\end{array}$ & $\begin{array}{l}5144 \\
\text { individuals } \\
\text { from } 111 \\
\text { different } \\
\text { species. }\end{array}$ & $\begin{array}{l}\text { At the community level, } \\
\text { evenness is more sensitive } \\
\text { to human disturbance than } \\
\text { richness of species than what is } \\
\text { commonly reported. }\end{array}$ & $08 / 2020$ \\
\hline $\begin{array}{l}\text { (Jacobs et al. } \\
\text { 2020) }\end{array}$ & $\begin{array}{l}\text { Impact on } \\
\text { accessibility, } \\
\text { management } \\
\text { \& research }\end{array}$ & $\begin{array}{l}\text { Quantitative } \\
\text { analysis. }\end{array}$ & U.S. & $\begin{array}{c}\text { Not } \\
\text { mentioned. }\end{array}$ & $\begin{array}{l}\text { New opportunities for research } \\
\text { collaborations and re-evaluate } \\
\text { current research. Management } \\
\text { opportunities from the greater } \\
\text { appreciation of parks as a } \\
\text { collective asset for human } \\
\text { health. }\end{array}$ & $04 / 2020$ \\
\hline $\begin{array}{l}\text { (Templeton } \\
\text { et al. 2021) }\end{array}$ & $\begin{array}{l}\text { Impact on } \\
\text { visitation }\end{array}$ & $\begin{array}{l}\text { Qualitative } \\
\text { analysis }\end{array}$ & $\begin{array}{l}\text { Southern } \\
\text { Utah, US. }\end{array}$ & $n=10$ & $\begin{array}{l}\text { A new demographic of travelers } \\
\text { emerged providing new busi- } \\
\text { ness segment. Environmental } \\
\text { impact of the new visitors, } \\
\text { because of lack of awareness. }\end{array}$ & \\
\hline $\begin{array}{l}\text { (Souza et al. } \\
\text { 2021) }\end{array}$ & $\begin{array}{l}\text { Impact of } \\
\text { limit mobility } \\
\text { on public } \\
\text { interest on } \\
\text { national } \\
\text { parks }\end{array}$ & $\begin{array}{l}\text { Quantitative } \\
\text { analysis }\end{array}$ & $\begin{array}{l}\text { Internatio- } \\
\text { nal level }\end{array}$ & $\begin{array}{l}\text { inter- } \\
\text { viewees. }\end{array}$ & $\begin{array}{l}\text { These different framings (pla- } \\
\text { ce-branding/ conservation) of } \\
\text { national parks influenced public } \\
\text { interest during the pandemic. }\end{array}$ & $07 / 2020$ \\
\hline $\begin{array}{l}\text { (Quesa- } \\
\text { da-Rodrí- } \\
\text { guez et al. } \\
\text { 2021) }\end{array}$ & $\begin{array}{l}\text { Impact on } \\
\text { monitoring }\end{array}$ & $\begin{array}{l}\text { Mixed } \\
\text { methods }\end{array}$ & Costa Rica & & $\begin{array}{l}\text { Monitoring efforts were } \\
\text { successful during the lockdown. } \\
\text { But environmental education } \\
\text { was not accomplished to its full } \\
\text { extent. }\end{array}$ & $08 / 2020$ \\
\hline $\begin{array}{l}\text { (Jones et al. } \\
\text { 2021) }\end{array}$ & $\begin{array}{l}\text { Impact on } \\
\text { local commu- } \\
\text { nity }\end{array}$ & $\begin{array}{l}\text { Mixed } \\
\text { methods }\end{array}$ & Wales, UK & $\begin{array}{l}\mathrm{n}=700 \\
\text { residents }\end{array}$ & $\begin{array}{l}\text { Potential existence of social } \\
\text { inequity inside the community } \\
\text { due to uneven sharing of bene- } \\
\text { fits from ecotourism. }\end{array}$ & $06 / 2020$ \\
\hline
\end{tabular}

Abbreviations: Protected Areas (PAs). Source: author own elaboration. 


\subsection{Subject of Study}

We retrieved and analyzed 14 journal articles which are related either to social, management, ecological or environmental aspects on PAs. Table 1 portrays a literature review summary table with the selected research articles.

Developing countries were represented in 50\% of the articles retrieved $(\mathrm{n}=7)$. Out of those, four examined Asian PAs (Cahyadi and Newsome 2021; China et al. 2021; Koju et al. 2021; Patterson Edward et al. 2021), followed by two that analyzed African conserved spaces (Anand and Kim 2021; Smith et al. 2021) and one study was located in Costa Rica, in Latin America (QuesadaRodríguez et al. 2021). Developed countries represented $42 \%$ of the articles retrieved $(n=6)$. Out of those, four evaluated PAs in the U.S. (Jacobs et al. 2020; Miller-Rushing et al. 2021; Templeton et al. 2021; Terry et al. 2021) and the rest in Europe (Jones et al. 2021; McGinlay et al. 2020). Finally, one article evaluated several national parks across the world (Souza et al. 2021).

Regarding the categories of PAs, seven articles analyzed national parks including marine national parks $(n=2466)$, while one studied geoparks $(n=21)$. Two papers examined natural reserves $(\mathrm{n}=2)$ and one studied urban protected areas (n=3). Finally, three articles evaluated nearly 8470 PAs.

Regarding management, six studies evaluated managerial and administrative responses to the outbreak of the virus which covered repercussions on tourism in conserved spaces, research projects, education, sources of founding and impact on local economies (Cahyadi and Newsome 2021; Jacobs et al. 2020; Miller-Rushing et al. 2021; Smith et al. 2021; Souza et al. 2021; Templeton et al. 2021). Another two analyzed the impact of the pandemic on communities living around or inside protected landscapes. These studies examined how daily life of locals was affected and how their relationship with the national parks changed as well. (Jones et al. 2021; McGinlay et al. 2020). Another article assessed the level of economic activities with light-data in the areas around and inside PAs (Anand and Kim 2021).

Regarding environment, two papers analyzed the influence of COVID-19 on PAs on water and sound pollution (Patterson Edward et al. 2021; Terry et al. 2021), while five examined the repercussions on wildlife and monitoring (China et al. 2021; Miller-Rushing et al. 2021; Patterson Edward et al. 2021; QuesadaRodríguez et al. 2021; Smith et al. 2021).

\subsection{Method of Analysis}

We examined the research methods of the articles retrieved and showed that a great variety of research methodology was used for analyzing the effects of the COVID-19 on PAs. These differences have to do with the diverse topics analyzed. 
Studies that evaluated ecological or environmental effects of COVID-19 on reserved areas mostly undergo quantitative analysis of data $(n=4)$. Two of them examined various environmental parameters (water quality and its components and noise pollution). Therefore, water samples and sound measures were collected and analyzed (Patterson Edward et al. 2021; Terry et al. 2021). In addition, three studies used observation and census to quantify and identify the density and diversity of species, mostly in marine reserves. In these articles, wildlife censuses were evaluated with ecology-related statistical analysis and assessment of quantitative data (China et al. 2021; Patterson Edward et al. 2021; Quesada-Rodríguez et al. 2021). One study about impacts on wildlife combined qualitative analysis (interviews) and quantitative analysis (observations) (Koju et al. 2021).

Among the articles that focused on social and management aspects, several relied on qualitative analysis $(n=5)$ (interviews and literature review) (Cahyadi and Newsome 2021; Jacobs et al. 2020; Miller-Rushing et al. 2021; Smith et al. 2021; Templeton et al. 2021). On the other hand, a few relied on a mixed approach, combining qualitative and quantitative analysis $(n=2)$. Data was obtained from a mix of review literature, interview questions, structure and semi-structure questionaries and surveys. (Jones et al. 2021; McGinlay et al.). Other studies articles evaluating social or economic impacts of the pandemic on PAs used quantitative analyses $(n=2)$, relying in statistical analysis using night-time lights data series (Anand and Kim 2021) and content analysis (Souza et al. 2021).

\subsection{Positive and negative impacts}

The positive and negative effects identified in the articles analyzed are summarized in Table 2 . The articles retrieved mainly examined the immediate responses and short-term effects while the long-term consequences were evaluated within a challenges and opportunities framework.

This systematic review identified a wide range of impacts of COVID-19 on PAs among the articles retrieved. 
Table 2. Negative and positive impacts of COVID-19 on PAs

\begin{tabular}{|c|c|c|}
\hline & Positive impacts & Negative impacts \\
\hline $\begin{array}{l}\text { Social } \\
\text { impacts }\end{array}$ & $\begin{array}{l}\text { Quieter atmosphere for locals. } \\
\text { Effective local partnerships. }\end{array}$ & $\begin{array}{l}\text { Unemployment. Unequal distribution } \\
\text { of benefits. Social tension. Loss } \\
\text { educational and recreational } \\
\text { opportunities. Lessen mental health } \\
\text { and quality of life }\end{array}$ \\
\hline Research & $\begin{array}{l}\text { Reconsideration of sampling designs, } \\
\text { methods, monitoring, and analyses. }\end{array}$ & $\begin{array}{l}\text { Projects and traineeship decreased. } \\
\text { Data-collection and monitoring was } \\
\text { disrupted. }\end{array}$ \\
\hline Management & $\begin{array}{l}\text { Innovative management strategies. } \\
\text { New communication channels and } \\
\text { new technologies introduced. }\end{array}$ & $\begin{array}{c}\text { Tasks and projects were reduced, } \\
\text { delay, or postpone. Manpower } \\
\text { challenges. }\end{array}$ \\
\hline Visitors & $\begin{array}{l}\text { Increased accessibility to PAs for } \\
\text { locals. New demographic of travelers. }\end{array}$ & $\begin{array}{l}\text { Fluctuation of visitors, overcrowding, } \\
\text { irresponsible behavior, scarce staff. }\end{array}$ \\
\hline Funding & Alternative sources of revenue. & $\begin{array}{l}\text { Loss of revenue, of financial } \\
\text { assistance, and income. }\end{array}$ \\
\hline Ecology & $\begin{array}{l}\text { Species richness in marine PAs } \\
\text { increased. }\end{array}$ & $\begin{array}{l}\text { Increase poaching, smuggling, forest, } \\
\text { and wildlife-related crimes. Increased } \\
\text { risk and extent of disturbance to } \\
\text { wildlife. }\end{array}$ \\
\hline Environment & Improved environmental parameters. & $\begin{array}{l}\text { Disturbance of ecosystems, damage } \\
\text { of infrastructure and unsustainable } \\
\text { environmental conditions. }\end{array}$ \\
\hline
\end{tabular}

Source: author own elaboration. 


\section{- $\quad$ Social impacts}

Some articles assessed the positive effects of COVID-19 on social aspects ( $n=5)$. In European national parks, the lockdown restrictions resulted in benefits for the local communities in terms of quieter walking and cycling paths and fewer non-local visitors in areas of natural beauty (Jones et al. 2021; McGinlay et al. 2020). Meanwhile, in African national parks, the lockdown and travel restrictions encourage the assistance of rangers to neighboring population which, in turn, enabled effective local partnerships required for implementing the social and economic development objectives from parks' authorities (Smith et al. 2021).

Several articles assessed the negative social impacts of the pandemic $(n=7)$, which were related to the disruption of the integrity and the sustainability of PAs. Namely, all studies reported reduction in economic activities, job opportunities, and household income for neighboring communities and for tourism-related industry. In turn, this gloomy outlook created tensions in the surrounding communities related to unequal distribution of the benefits from PAs' activities, ecotourism, and other related activities. Other social tensions reported were related to the appearance of non-locals within the surroundings of protected spaces (strangers who could potentially carry the virus), the noncompliance of sanitary measures, and irresponsible behavior inside PAs (such as crowding, parking, littering, and hiking outside safety zones). In addition, these studies examined the stress and uncertainty lived by park's staff, the formal and informal workers in the tourism sector and the communities who traditionally benefited of extractive activities inside PAs (Anand and Kim 2021; Cahyadi and Newsome 2021; Jacobs et al. 2020; Jones et al. 2021; McGinlay et al. 2020; Miller-Rushing et al. 2021; Smith et al. 2021).

Furthermore, some papers suggested that restrictions led to reduced number of visitors, of volunteers and researchers working on PAs, loss of educational opportunities (mostly for children) and deprivation of recreational and sport activities $(\mathrm{n}=5)$. These adverse effects turned into loss of motivation or interest on PAs and negative consequences for mental health and quality of life of local community, visitors, and staff (Jones et al. 2021; Miller-Rushing et al. 2021; Quesada-Rodríguez et al. 2021; Smith et al. 2021; Souza et al. 2021).

\section{- $\quad$ Research}

Some studies analyzed positive impacts and opportunities of research and $(n=4)$. They concluded that the pandemic incentivized researchers to re-examine their sampling designs, monitoring, and to re-evaluate current thinking. It also encouraged scientists to consider new methods and methodologies, including new forms of data collection that take into account social distancing measures, the access to online tools and new channels of communication. Additionally, 
the pandemic stimulated cross disciplinary collaboration, promoted new partnerships, and provided opportunities to enhanced collaboration and data sharing. Furthermore, the uprise of online education programmes enhanced learning opportunities for underrepresented groups and increased formalization of learning instances. In places were research activity continued, the pandemic benefited the monitoring of species, promote a faster data collection, the consolidation of projects and the innovation within management decisions (Jacobs et al. 2020; Miller-Rushing et al. 2021; Quesada-Rodríguez et al. 2021; Smith et al. 2021).

On the other hand, these studies also reported negative impacts of COVID-19 on research on PAs. The pandemic led to decreased revenue for PAs, which in turn promoted budget cuts on investigation. Moreover, this situation involved difficult trade-offs between projects and educational opportunities. In addition, the restrictions and lockdowns generated a drastic decrease of the number of research conducted while social studies were also significantly affected. It also disrupted data-collection, monitoring and long-term research. Additionally, the pandemic prompt fewer traineeship and volunteer opportunities on reserved areas, which in turn decreased the research and development on PAs. Similarly, the lack of volunteer personnel led to extrawork and fatigue from research assistants.

\section{- $\quad$ Management}

This study assesses repercussion of COVID-19 on management. Several studies $(n=5)$ reported beneficial effects and new opportunities on management triggered by the pandemic. The lockdowns and restrictions created opportunities to test new management approaches, innovative strategies to manage overcrowding, new forms of collaboration, modern communication channels and innovative engagement strategies. The pandemic also encouraged PAs' managers to evaluate how visitors responded to new regulations concerning social distance measures. Additionally, it promoted remote work of staff, which led to new opportunities regarding access to new technologies, new channels of communication, and cuts in administrative and transportation costs. Therefore, COVID-19 served as a catalyst for more effective collaboration, creative thinking in management and marketing (Jacobs et al. 2020; Jones et al. 2021; MillerRushing et al. 2021; Smith et al. 2021). Besides, one study reported that closure of parks due to the new virus was an opportunity to undertake recovery work at damaged sites (Cahyadi and Newsome 2021).

Nevertheless, negative impacts outweighed the benefits of the pandemic on management of PAs because COVID-19 reduced, delayed, or postponed direct and indirect management actions and techniques. On one hand, safety measures led to challenges in manpower. For example, these measures 
implied considering the human carrying capacity of disease, thus affecting administrative tasks and routine activities such as attention to public, control, monitoring, and preservation activities. In addition, these measures conflicted with the aim to decrease wildlife and ecosystem disturbance (McGinlay et al. 2020). Similarly, lack of staff and social distancing measures made rangers face stress and pressure in preserving wildlife against smuggling, hunting and illegal logging (Cahyadi and Newsome 2021; Jacobs et al. 2020; McGinlay et al. 2020; Miller-Rushing et al. 2021; Templeton et al. 2021).

\section{- Visitors}

On the other hand, the sanitary crises led to reduction or fluctuation of visitors to PAs. Many authors point out that carrying capacity debates and heavy visitation problems were re-established in PAs in Asia, Europe, U.S, and Africa $(n=7)$. The pandemic promoted problems of overcrowding, irresponsible behavior of park's users, lack of staff and tensions between locals and nonlocal visitors (mostly after the ease of restrictions on reserved areas and parks). These issues further led to pressure on wildlife and ecosystems and to unsustainable environmental conditions. They also generated damage to PAs' resources and infrastructure.

Additionally, the fluctuation of tourists led to negative economic impact and inequality in the distributions of benefits from tourism among locals. The financial capacity of the protected landscapes was also affected (Cahyadi and Newsome 2021; Jones et al. 2021; McGinlay et al. 2020; Miller-Rushing et al. 2021; Quesada-Rodríguez et al. 2021; Smith et al. 2021; Templeton et al. 2021). In addition, overcrowding and safety measures led to negative perceptions of the public regarding their visiting experience. Some authors point out that if the visitor experience becomes diminished, then this may compromise recreation-related health benefits from PAs (Cahyadi and Newsome 2021; Jacobs et al. 2020).

On positive terms, some studies $(n=4)$ suggested that new type of travelers emerged after restrictions eased, thus, creating a new business segment. Thus, a new profile of visitors generated new demands and more marketing opportunities. Similarly, these studies highlighted an increased accessibility of local or regional visitors to the reserved areas and parks (Jacobs et al. 2020; Jones et al. 2021; Miller-Rushing et al. 2021; Templeton et al. 2021).

\section{- $\quad$ Funding}

Financial aspects were a key issue discussed among articles reviewed. Several of them $(n=9)$ concluded that COVID-19 reduced sources of funding because of reduction in public mobility, total or partial closure of parks, introduction 
of safety protocols and because partner organizations who supported PAs had to make major cutbacks. In turn, loss of revenue disrupted fundamental parks operations, monitoring programs, research projects and public engagement activities of PAs. As a cascade effect, loss of revenue not only affected PAs management but also caused negative social impacts, such as loss of family income, unemployment, and loss of revenue for formal and informal businesses and for actors inside the tourism industry. (Anand and Kim 2021; Cahyadi and Newsome 2021; Jones, Graziano, et al. 2020; McGinlay et al. 2020; Miller-Rushing et al. 2021; Quesada-Rodríguez et al. 2021; Smith et al. 2021; Souza et al. 2021; Templeton et al. 2021)

In addition, the loss of revenue for formal and informal businesses increased dependency of people on natural resources as a substitute for cash. This situation intensified poaching and illegal activities within conserved spaces, putting pressure on biodiversity (Miller-Rushing et al. 2021; Koju et al. 2021). In PAs where practices of extraction of natural resources are traditionally allowed, the restrictions following the outbreak of COVID-19 deprived local users from access to such resources, which meant a loss of income and food security (Smith et al. 2021). These articles concluded that dependence on a single income stream (tourism) leaves PAs vulnerable, leading to uncertainty and major budget cuts.

On positive grounds, the pandemic created opportunities to try unconventional sources of funding. To achieve growing and balancing income streams, PAs' managers in Africa identified an alternative funding model which consisted of creating a diversified portfolio made out form a mix of traditional sources of revenue (such as tourism, government subsidies and donations) and innovative options like green bonds, green taxes, and carbon offsets (Smith et al. 2021).

\section{- $\quad$ Ecology and environment}

Regarding wildlife conservation, some studies retrieved $(n=4)$ reported an increase in illegal activities, namely poaching and smuggling, logging, and wildlife-related crimes. For example, the pandemic situation promoted a rise in injuries among wildlife inside PAs in Nepal and Indonesia. In Africa, where there are national parks with international boundaries, the pandemic led to difficulties for rangers to control illegal incursions from other countries (Cahyadi and Newsome 2021; Koju et al. 2021; Smith et al. 2021).

Some authors concluded that the increased visitation, along with the lack of tourist guides, the introduction of safety measures, and the new profiles of visitors, all together increased risk and extent of disturbance to wildlife in remote sensitive areas of PAs (McGinlay et al. 2020; Miller-Rushing et al. 2021; Templeton et al. 2021). 
On the other hand, some studies $(n=2)$ reported positive impacts in terms of biodiversity conservation in marine PAs. Lockdown restrictions led to absence of human's extractive activity at specific points of marine protected spaces. Based on fish diversity data, both research articles stated that this situation promoted a change in community structure and behavioral response of species in two protected reefs in Israel and India. This resulted, in both cases, in elevated species richness, in terms of increased evenness, diversity and density. However, they reported no changes in fish population. Therefore, the short-term impact of COVID-19 showed that some human impacts on coral reefs can be reversible, specially related to fish behavior (China et al. 2021; Patterson Edward et al. 2021).

Another study concluded that the benefits from the pandemic were related to monitoring activities. It explained that the absence of visitors and students benefited monitoring by minimizing the number of turtles missed. In addition, the COVID-19 restrictions resulted positively in the highest encounter rate of nesting leatherback turtles seen in Pascuara Reserve, Costa Rica (Quesada-Rodríguez et al. 2021).

On environmental terms, COVID-19 led to the reduction of adverse man-made factors on the environment. Consequently, the environmental health of PAs improved. One article reported that, in one marine national park, the situation induced by the new virus led to the scaling down of salinity, turbidity, and reduction of nutrient levels in water. The study also found decreased concentrations of sediments, and of heavy metals too. Also, it reported that microbial parameters fell significantly (Patterson Edward et al. 2021). In addition, one study suggested that the reduced human mobility meant a relief for some ecological stressors related to high visitation rates at popular and iconic parks and PAs (Jacobs et al. 2020).

On the other hand, one article suggested two directions for the impact of COVID-19 on sound levels. The authors found a decrease in noise pollution during the lockdown at two urban PAs in Boston. However, a third park analyzed, reported increased sound levels because of cars going faster on the nearby highway due to the absence of traffic jams during the mobility restrictions (Terry et al. 2021).

\section{Discussion}

The results confirm the social relevance of PAs. The pandemic highlighted the interdependencies between people and nature and increased the awareness of the importance of parks and reserves on mental and physical health and the integrity of communities. These findings contribute to the literature 
discussing the social impact of PAs. In addition, COVID-19 encouraged new ways of connecting people to national parks in diverse ways, ranging from new partnerships or collaborations to new forms of online and remote engagement and learning opportunities.

On the other hand, results highlighted that a wide array of actors is directly or indirectly dependent on PAs for livelihood thus they are particularly vulnerable to the repercussions of the pandemic on PAs, such as partial or total closure of national parks.

In addition, the sanitary crises led to social tensions between different PAs users along the cases examined. However, the problems differed between regions. In Europe, social tensions were related to irresponsible behavior of tourists such a littering and parking. Also, tensions arose because of the presence of non-locals within national parks boundaries (foreigners who could potentially carry the virus). On the other hand, in Africa and Asia, social tensions were related to deprivation of extractive resources from parks and loss of formal and informal jobs. Also, COVID-19 increase economic pressure on the population, thus leading to increased wildlife and forest-related illegal activities in protected spaces.

Results demonstrate that PAs management practiced adaptive management solutions to confront the negative effects from the pandemic. However, COVID-19 exposed that traditional management structures, processes and procedures were insufficient to cope with a very sudden and dramatic disruption to typical visitation patterns and conditions (Templeton et al. 2021). Besides these challenges, the pandemic crisis has made the job of PA management more complex and shifted the balance of priorities in order to comply with social-distancing restrictions and new social fears regarding the virus.

COVID-19 showed the financial vulnerability of PAs across the world. Most of the conserved areas analyzed rely mostly on a single source of revenue: tourism. While this industry was stable through past years and while PAs have multiple economic and non-economic benefits out from visitation, COVID-19 had devastating effects on tourism industry. In consequence, PA management bodies and local communities should be supported during such crises where their income becomes more variable and unpredictable (McGinlay et al. 2020). For the long-term, despite conservation funding is a controversial topic (Evans et., al., 2012), sources of revenue for protected spaces should be reconsidered.

Results show that tourism is not a perfect solution for biodiversity conservation, not only because of financial vulnerability but because of fluctuation of visitors. Records of high visitation registered after reopening of national parks affected infrastructure and ecosystems. In consequence, it is important that longer-term solutions are introduced by management 
authorities. For example, a careful management of the spatial distribution of visitors in PAs may be necessary (McGinlay et al. 2020).

Due to the pandemic situation, PAs were largely included in the global digital tendency. Case studies showed that PAs successfully implemented new channels of communications and technologies for management and engagement strategies. The same integration of technological solutions can be found in research and monitoring. Also, online recreational activities and learning opportunities have come to stay.

Regarding wildlife it is important to note that some human disturbances on fish population inside coral reefs can be quickly reversed thanks to our absence in specific points of marine protected spaces. These finding are in line with scholar literature that recommended increasing the diameter of existing marine PAs, reducing the spacing between protected networks and establishing new conserved areas in order to enhance the effectiveness of marine PAs (Mora et al. 2008).

The results of the systematic review confirm that, despite the importance of PAs for international conservation efforts, these protected landscapes have substance social and economic implications. COVID-19 disrupted not only environmental and ecological aspects but people and their economies as well, thus the overall sustainability of these areas was compromised with the sanitary crises.

On the other hand, we could see that, despite COVID-19 has introduced many challenges to PAs, new opportunities arise as well, and stakeholders should address them to promote new and more sustainable ways to manage protected landscape (McGinlay et al. 2020).

One of the most notable limitations for this study is the lack of articles retrieved in different languages to cover more case studies around the world, especially from developing countries. Also, other than research articles, reports should be included in future studies. Additionally, it must be noted that COVID-19 is ongoing in some regions of the world, so this study could benefit from the research articles published at a later more appropriate date. Furthermore, due to the scope of the review and content of the different studies certain issues remain unanswered revealing the need for additional research in the future. Acknowledging that social support is crucial for ecological effectiveness of PAs it is important to capture the perceptions of stakeholders on protected landscapes. Thus, an unexplored question is how the perceptions of actors (negatively and positively affected by the impacts pf the pandemic on PAs) changed before and after the pandemic.

This study has some implications for future studies. While PA management authorities were largely focused on coping with the short-term impacts of the pandemic, few comments were made about the longer-term 
implications of the pandemic. Thus, long-term impacts of COVID-19 should be further addressed. These effects will depend on a wide range of factors such as the medium to long-term impact on the economy and the future actions of governance actors (McGinlay et al. 2020).

In addition, this systematic review showed few cases were the authors made a joint assessment regarding ecological, economic, and social impact of the pandemic on PAs. New directions of research should look after interdisciplinary cooperation to evaluate, with an integral view, the repercussions of the sanitary crises on PAs.

\section{Conclusion}

In this systematic review, we analyzed the literature about the impacts of COVID-19 on various aspects of PAs across the world. The articles retrieved showed alterations of the management, visitation, research, monitoring, and the economic activity of a wide range of actors, especially, people from the tourism industry, researchers, park' staff and local communities. The pandemic led to loss of revenue and proved the vulnerability of PAs that depended mostly on one single source of income. It also generated an inequal access to PAs' resources and benefits from tourism among social groups. It also involved changes in public interest towards PAs and the way people got in contact with nature.

In addition, in certain scenarios, the pandemic increased the pressure and disturbance on species conservation and conserved landscape. In protected marine ecosystems, the restrictions impacted positively on wildlife biodiversity.

COVID-19 made humankind to rethink everything through the lens of health. In PAs management bodies, this situation involved difficult trade-offs regarding operations and activities which complied or not with safety measures. There were also difficult trade-offs that had to do with budget cuts. However, due to the pandemic scenario, the priorities had to be reevaluated and settled, resulting this in new opportunities for management, founding, visitation, and research and monitoring.

This study contributes to broaden our knowledge about PAs. With a better understanding on the repercussions of COVID-19, the decisions over carrying capacity of parks, sources of founding, and management activities can be better assessed. Also, new opportunities for research, monitoring and preservation of species can be informed. In addition, this study is relevant to reconsider conservation strategies and sustainable development policies. 


\section{References}

Anand, Anupam, and Do-Hyung Kim. 2021. "Pandemic Induced Changes in Economic Activity around African Protected Areas Captured through Night-Time Light Data." Remote Sensing 13(2):314. doi: 10.3390/rs13020314.

Beller, Elaine M., Paul P. Glasziou, Douglas G. Altman, Sally Hopewell, Hilda Bastian, Iain Chalmers, Peter C. Gøtzsche, Toby Lasserson, and David Tovey. 2013. "PRISMA for Abstracts: Reporting Systematic Reviews in Journal and Conference Abstracts." PLoS Medicine 10(4): 1001419. doi: 10.1371/ journal.pmed.1001419.

Bennett, Nathan J., Antonio Di Franco, Antonio Calò, Elizabeth Nethery, Federico Niccolini, Marco Milazzo, and Paolo Guidetti. 2019. "Local Support for Conservation Is Associated with Perceptions of Good Governance, Social Impacts, and Ecological Effectiveness." Conservation Letters 12(4).

Cahyadi, Hery Sigit, and David Newsome. 2021. "The Post COVID-19 Tourism Dilemma for Geoparks in Indonesia." Internati onal Journal of Geoheritage and Parks. doi: 10.1016/j.ijgeop.2021.02.003.

Camilo Mora, Serge Andréfouët, Mark J. Costello, Christine Kranenburg, Audrey Rollo, John Veron, Kevin J. Gaston, and Ransom A. Myers. 2006. "Coral Reefs and the Global Network of Marine Protected Areas." Science 312:1750-51.

China, Victor, Assaf Zvuloni, Uri Roll, and Jonathan Belmaker. 2021. "Reduced Human Activity in Shallow Reefs during the COVID-19 Pandemic Increases Fish Evenness." Biological Conservation 257: 109103. doi: 10.1016/j.biocon. 2021.109103.

Department of Land Economy - University of Cambridge. n.d. "FIDELIO | Forecasting Social Impacts of Biodiversity Conservation Policies in Europe." Retrieved June 20, 2021 (https://www.fidelio.landecon.cam.ac.uk/).

Evans, Darren \& Barnard, Phoebe \& Koh, Lian \& Chapman, Colin \& Altwegg, Res \& Garner, Trenton \& Gompper, M. \& Gordon, Iain \& Katzner, Todd \& Pettorelli, Nathalie. 2012. "Funding nature conservation: Who pays? " Animal Conservation. 15. 215216. 10.1111/j.1469-1795.2012.00550.x.

Guidetti, Paolo, Marco Milazzo, Simona Bussotti, Andrea Molinari, Matteo Murenu, Antonio Pais, Nunziacarla Spanò, Raffaella Balzano, Tundi Agardy, Ferdinando Boero, Giancarlo Carrada, Riccardo Cattaneo-Vietti, Angelo Cau, Renato Chemello, Silvestro Greco, Antonio Manganaro, Giuseppe Notarbartolo di Sciara, Giovanni Fulvio Russo, and Leonardo Tunesi. 2008. "Italian Marine Reserve Effectiveness: Does Enforcement Matter?" Biological Conservation 141(3):699-709. doi: 10.1016biocon.2007.12.013.

Gusenbauer, Michael, and Neal R. Haddaway. 2020. "Which Academic Search Systems Are Suitable for Systematic Reviews or Meta-Analyses? Evaluating Retrieval Qualities of Google Scholar, PubMed, and 26 Other Resources." Research Synthesis Methods 11(2): 181-217. https://doi.org/10.1002/JRSM.1378.

Jacobs, Lara A., Michael P. Blacketer, Brian A. Peterson, Elena Levithan, Zachary A. Russell, and Michael Brunson. 2020. "Responding to COVID-19 and Future Times of Uncertainty: Challenges and Opportunities Associated with Visitor Use, 
Management, and Research in Parks and Protected Areas." Parks Stewardship Forum 36(3).doi: 10.5070/p536349860.

Jones, Nikoleta, Mariagrazia Graziano, and Panayiotis G. Dimitrakopoulos. 2020. "Social Impacts of European Protected Areas and Policy Recommendations." Environmental Science and Policy 112:134-40.

Jones, Nikoleta, Chrisovalantis Malesios, Apostolos Kantartzis, and Panayiotis G. Dimitrakopoulos. 2020. "The Role of Location and Social Impacts of Protected Areas on Subjective Wellbeing." Environ. Res. Lett 15:114030. doi: 10.1088/1748-9326/abb96e.

Jones, Nikoleta, James McGinlay, and Panayiotis G. Dimitrakopoulos. 2017. "Improving Social Impact Assessment of Protected Areas: A Review of the Literature and Directions for Future Research." Environmental Impact Assessment Review 64:1-7.

Jones, Nikoleta, James McGinlay, Angela Jones, Chrisovalantis Malesios, Jens Holtvoeth, Panayiotis G. Dimitrakopoulos, Vassilis Gkoumas, and Andreas Kontoleon. 2021. "COVID-19 and Protected Areas: Impacts, Conflicts, and Possible Management Solutions." Conservation Letters.

Koju, Narayan Prasad, Ram Chandra Kandel, Hari Acharya, Bed Dhakal, and Dinesh Bhuju. 2021. "Covid-19 Lockdown Sets Wildlife Free but Increases Poaching Threats in Nepal." Authorea Preprints. doi: 10.22541/AU.161701344.41884506/V1.

Loos, Jacqueline. 2021. "Reconciling Conservation and Development in Protected Areas of the Global South." Basic and Applied Ecology. doi: 10.1016/j.baae.2021.04.005.

Ma, Ben, Yuqian Zhang, Yilei Hou, and Yali Wen. 2020. "Do Protected Areas Matter? A Systematic Review of the Social and Ecological Impacts of the Establishment of Protected Areas." International Journal of Environmental Research and Public Health 17(19):1-13.

McGinlay, James, Vassilis Gkoumas, Jens Holtvoeth, Ruymán Federico Armas Fuertes, Elena Bazhenova, Alessandro Benzoni, Kerstin Botsch, Carmen Cabrera Martel, Cati Carrillo Sánchez, Isabel Cervera, Guillermo Chaminade, Juliana Doerstel, Concepción J. Fagund. García, Angela Jones, Michael Lammertz, Kaja Lotman, Majda Odar, Teresa Pastor, Carol Ritchie, Stefano Santi, Mojca Smolej, Francisco Soriano Rico, Holly Waterman, Tomasz Zwijacz-Kozica, Andreas Kontoleon, Panayiotis G. Dimitrakopoulos, and Nikoleta Jones. 2020. "The Impact of COVID-19 on the Management of European Protected Areas and Policy Implications." Forests 11(11):1-15. doi: 10.3390/f11111214.

Miller-Rushing, Abraham J., Nicole Athearn, Tami Blackford, Christy Brigham, Laura Cohen, Rebecca Cole-Will, Todd Edgar, Elizabeth R. Ellwood, Nick Fisichelli, Colleen Flanagan Pritz, Amanda S. Gallinat, Adam Gibson, Andy Hubbard, Sierra McLane, Koren Nydick, Richard B. Primack, Susan Sachs, and Paul E. Super. 2021. "COVID-19 Pandemic Impacts on Conservation Research, Management, and Public Engagement in US National Parks." Biological Conservation 109038. doi: 10.1016/j.biocon.2021.109038.

Patterson Edward, J. K., M. Jayanthi, H. Malleshappa, K. Immaculate Jeyasanta, R. L. Laju, Jamila Patterson, K. Diraviya Raj, G. Mathews, A. S. Marimuthu, and Gabriel Grimsditch. 2021. "COVID-19 Lockdown Improved the Health of Coastal 
Environment and Enhanced the Population of Reef-Fish." Marine Pollution Bulletin 165:112124. doi: 10.1016/j.marpolbul.2021.112124.

Pullin, Andrew S., and Gavin B. Stewart. 2006. "Guidelines for Systematic Review in Conservation and Environmental Management." Conservation Biology 20(6):1647-56.

Quesada-Rodríguez, Claudio, Catherine Orientale, Jessica Diaz-Orozco, and Bárbara Sellés-Ríos. 2021. "Impact of 2020 COVID-19 Lockdown on Environmental Education and Leatherback Sea Turtle (Dermochelys Coriacea) Nesting Monitoring in Pacuare Reserve, Costa Rica." Biological Conservation 255:108981. doi: 10.1016/j.biocon.2021.108981.

Secretariat of the Convention on Biological Diversity. 2020. Global Biodiversity Outlook 5. Montreal.

Smith, M. Kyle S., Izak P. J. Smit, Louise K. Swemmer, Mohlamatsane M. Mokhatla, Stefanie Freitag, Dirk J. Roux, and Luthando Dziba. 2021. "Sustainability of Protected Areas: Vulnerabilities and Opportunities as Revealed by COVID-19 in a National Park Management Agency." Biological Conservation 255:108985. doi: 10.1016/j.biocon.2021.108985.

Souza, Carolina N., Ana Carla Rodrigues, Ricardo A. Correia, Iran C. Normande, Hugo C. M. Costa, Jhonatan Guedes-Santos, Ana C. M. Malhado, Adriana R. Carvalho, and Richard J. Ladle. 2021. "No Visit, No Interest: How COVID-19 Has Affected Public Interest in World's National Parks." Biological Conservation 256:109015. doi: 10.1016/j.biocon.2021.109015.

Templeton, A. J., Kelly Goonan, and Alan Fyall. 2021. "COVID-19 and Its Impact on Visitation and Management at US National Parks." International Hospitality Review ahead-of-print(ahead-of-print). doi: 10.1108/ihr-08-2020-0039.

Terry, Carina, Matthew Rothendler, Lucy Zipf, Michael C. Dietze, and Richard B. Primack. 2021. "Effects of the COVID-19 Pandemic on Noise Pollution in Three Protected Areas in Metropolitan Boston (USA)." Biological Conservation 256:109039. doi: 10.1016/j.biocon.2021.109039.

UNEP-WCMC, and IUCN. 2020. "Protected Planet Report 2020." Retrieved June 20, 2021 (https://livereport.protectedplanet.net/). 